\title{
Internalization of the Value of Political Education Through the Contextual Teaching and Learning (CTL) Approach in Citizenship Education Subjects in the Digital Era
}

\author{
Asep Nurjaman ${ }^{1, *}$, Dasim Budimansyah ${ }^{2}$ \\ ${ }^{1,2}$ Universitas Pendidikan Indonesia, Bandung, Indonesia \\ ${ }^{*}$ Corresponding author.E-mail : asepnurjaman@upi.edu
}

\begin{abstract}
The Recent political developments in Indonesia, especially the political awareness of the younger generation who lack political education, became the initial concern of this research. This study aims to describe the process of internalizing the values of Political Education through the Contextual Teaching and Learning (CTL) approach in Citizenship Education, which aims to increase political awareness of state high school students in Garut Regency. Instilling the values of Political Education that is formed in high school students will avoid apathy. The research method that can be used to produce such a product is research and development (R\&D). This article argues that the CTL approach is an important instrument for internalizing the values of political education for students. In addition, this approach helps students to understand the subject in the context of everyday life, personal, social and cultural circumstances of the community. This approach also has implications for increasing political literacy, namely the ability to think positively and constructively in responding to political problems. To some extent, CTL also has an impact on more substantive political awareness among high school students.
\end{abstract}

Keywords: Citizenship Education, CTL, Digital era, Political Education, Value Internalization.

\section{INTRODUCTION}

It is a deep concern if we observe the development of our society since the reformation era in 1998, especially if we look at it from the perspective of a value system that is becoming increasingly shattered.

Indonesia today is being hurt and hurt by the actions of elites, public officials, and politicians. They are heavily involved in cases of corruption, conflicts of interest, and bureaucratic fragility. We may be tired, but the fate of Indonesia is indeed in the trap of political practice without ethics. This condition is feared to be the cause of public apathy towards politics.

Apathy is an attitude in which there is no sympathy and enthusiasm for an object. Apathy can also be interpreted as being indifferent or not caring. So it can be said that political apathy is a lack of sympathy and enthusiasm for political developments which leads to an attitude of indifference.

Apathy is not a new thing in Indonesian politics. Political apathy has existed for a long time but only began to be discussed when the reformation period began. Until now, political apathy remains a matter that still deserves to be discussed. Especially now is the Digital era where everyone is free to access information and is free to voice opinions on social media.

Political apathy cannot be underestimated considering that Indonesia is a democratic country where people are free to express their opinions against the authorities. Therefore, community participation is very necessary for the achievement of a prosperous Indonesia. Whether we realize it or not, political apathy can have a negative impact on society or the government. Related to this, Noam Chomsky (2016) states that as long as people are passive, apathetic, and distracted by consumerism or hatred in the husk, rulers will do as they please and those who can survive will be left to reflect on the consequences. [1].

Therefore, as a good Indonesian citizen, you should understand more about the political conditions in Indonesia. Avoid being apathetic and cultivate concern for political movements in Indonesia. Being apathetic is not at all the identity of the Indonesian 
people because independence will never be taken if the Indonesian people at that time were apathetic.

In an effort to understand the political conditions in Indonesia and at the same time anticipate apathy, it is necessary for the public to receive proper political education. Political education should start from the youth as the backbone of the country because it is on their shoulders that the future of this nation will depend.

Based on the description and explanation above, the researcher tries to raise the title: "Internalization of Political Education Values Through Contextual Teaching And Learning (CTL) Approaches in Citizenship Education Subjects.

Instilling political concepts at a young age, especially among high school students, is very important so that they do not get the wrong and wrong concept about politics. The importance of political education in adolescence will determine the high level of one's political awareness. The earlier an individual learns about politics, the higher his awareness of wanting to participate directly and being able to carry out responsibilities as a good citizen.

David Easton in Sirozi (2005, p. 49) says that 'one of the fundamental conditions for maintaining a political system is that when the younger generation in a society reaches adulthood, they must master science, values, and attitudes as expected by members and the existing system' [2].

Sudijono Sastroatmodjo (1995, p. 27) commented on the relationship between education and a person's level of political awareness as follows:

The level of education has an important role in increasing political awareness. The higher the level of public education, the higher the political awareness. Vice versa, the lower the level of public education, the lower the level of public political awareness.[3].

Students gain knowledge and understanding of politics in schools through Citizenship Education lessons. It can be said that all subjects have a good goal, namely educating students so that they can become citizens who are in accordance with expectations. But basically, special subjects that have the task of educating students to become good citizens are left to the subjects of Citizenship Education because the material contained in it raises a lot about politics. Schools with various instruments including curricula, textbooks, teaching methods, existing school organizations, classroom environments, students, teachers, administrative structures and others, can be explicitly or implicitly linked to the transition of a fundamental political orientation. The basic political orientation is usually formed from an early age. The political orientation formed at that age will be deeply rooted and will continue throughout life, unless there is a very strong environment that influences the individual.

Political awareness does not only include cognitive aspects but includes affective and psychomotor aspects. Therefore, the subject of Citizenship Education is considered appropriate because it is directly able to provide complete facilities for students to be able to develop these three aspects in understanding various concepts about politics.

Based on the description above, the researcher tries to raise the title: "Internalization of Political Education Values Through Contextual Teaching And Learning (CTL) Approaches in Citizenship Education Subjects.

\section{THEORETICAL REVIEW}

\subsection{Value Internalization}

Value is something that individuals use in selecting and justifying behavior and evaluating the actions of others (including oneself) and events. The values held by individuals become the basis for them in evaluating an event so as to give meaning to the event, including natural disasters. Cultural Values are the core of culture as values that are believed to be good or bad, what they think they should and shouldn't do, what they yearn for or don't want. These cultural values are a special basis for expecting people to behave properly at the right time. Cultural values include Intellectual Autonomy, Affective Autonomy, Attachment, Hierarchy, Harmony, and Mastery [4]. In relation to the Internalization of Values, (Mulyasa, 2014, p. 167) states that the internalization of values is an effort to appreciate and explore values so that they are embedded in every human being.[5].

Internalization of values seeks to present something (value) that originally existed in the outside world to become an internal characteristic of a person or institution (6). Value is an individual or group idea about something that is good, right and wise, so that the idea has value and quality and feasibility as a guide in human life (7). "Students who excel in school and participate in extracurricular activities experience more equity than other students"[8]. Therefore, activities outside the classroom are the dominant factors affecting students' ability to study in higher education. Values and morals are very important for human life, because both are important for human life [9]. This vision emphasizes that values and morality are important aspects in human life for human survival in the dynamics of society. Furthermore, regarding the internalization of values, particularly in relation to character education, Pearson \& Nicholson (2000, p.245) states that: "The ideal comprehensive character education program is a collaborative effort of administrators, teachers, and counselors sharing two tasks. One is to encourage parental involvement and the other is to be a role model for students" [10]. The 
statement implies that an ideal and comprehensive character education program in practice requires synergy between teachers, administrators, supervisors and parents of students.

\subsection{Political Education}

The definition of political education is different from the notion of education and politics. Therefore, education and politics have different meanings and purposes (11). Most westerners think that political education is synonymous with indoctrination and totalitarianism (12). There are at least three aspects in political education, including cognitive aspects related to political knowledge, affective aspects in shaping the character of citizens, and psychomotor aspects in developing citizen skills (13). Based on this view, it is concluded that in defining political education, more emphasis is placed on the content of concepts and objectives. Related to the notion of political education, Sumantri (2003) states that political education is a process of studying and understanding the rights, obligations, and responsibilities of every citizen in the life of the nation" (14). In line with Sumantri's opinion, Kartono (2009) revealed that political education is a systematic effort to shape individuals into political awareness and political behavior in achieving political goals (15). Political education is an awareness effort to instill a set of values and attitudes that can be used for the public interest [16]. According to Rusadi Kantaprawira (2004, p. 55).), political education is to increase people's knowledge so that they can participate optimally in the political system. In accordance with the notion of people's sovereignty or democracy, the community must be able to carry out the task of participation. Forms of political education can be done through: a) Reading materials such as newspapers, magazines, and other forms of mass publications which usually form public opinion b) Radio and television broadcasts as well as films (audiovisual media). c) Institutions or associations in the community such as mosques or churches where sermons are delivered, as well as formal and informal educational institutions (17). Then Surbakti (1999, p.117) suggests that political socialization is divided into two, namely political education and political indoctrination. Political education is a dialogical process between the giver and the receiver of the message. Through this process, community members recognize and learn the values, norms, and political symbols of their country from various parties in the political system such as schools, government, and political parties.[18]

\subsection{Contextual Teaching And Learning}

Contextual Teachng and Learning is an alternative to conventional or traditional learning models [19]. In developed countries this contextual approach has long been used in the learning process in school classrooms. Education experts generally have relatively the same view and agree on this contextual learning. Elaine B.
Johnson (2011, p. 64) for example, suggests that "The CTL system is an educational process that aims to help students see meaning in academic material, they learn by connecting academic subjects with the context of their daily lives., that is, in the context of their personal, social and cultural circumstances." [21]. the essence of the contextual approach is learning that has the aim of helping students to see the meaning of academic material with the context of their lives both as personal, social, and including their culture. The contextual learning approach is based on several theories: (1) Knowledge-Based Constructivism. This theory emphasizes the importance of developing students' ability to build their own knowledge through active involvement in the teaching and learning process; (2) Effort-Based Learning / Incremental Intelligence Theory. The theory emphasizes the importance of striving to achieve learning goals that will motivate a person to engage in activities related to commitment to learning; (3) Socialization. This theory views that learning is a social process that determines learning objectives, therefore social and cultural factors need to be considered in teaching planning; (4) Situation Learning (Situated Learning). This theory emphasizes that knowledge and learning must be conditioned in certain physical and social contexts (community, home, etc.) in order to achieve learning objectives; (5) Distribution Learning (Distributed Learning). This theory emphasizes that humans are an integral part of the learning process, therefore they must share knowledge and tasks with other individuals and the surrounding environment. [22]

\subsection{Civic Education}

The definition of Citizenship Education based on the Regulation of the Minister of National Education Number 22 of 2006 concerning Content Standards explains that the Primary and Secondary Education Units are subjects that focus on the formation of citizens who understand and are able to carry out their rights and obligations. become a smart, skilled, and intelligent Indonesian citizen. and character as mandated by Pancasila and the 1945 Constitution. [23].

In general, Citizenship Education is a process that influences beliefs, commitments, abilities, and actions as permanent members and prospective members in society (24). Recent research on Citizenship and Ethics Education (CEE) in Ethiopia reveals the need for improvement in several areas related to the current curriculum [25]. Citizenship Education is considered as a way to gain citizen participation in government (26). The purpose of civic education is to create citizens who will participate in the democratic process. (27). There are different definitions of Citizenship Education. First, it can be interpreted as a forum for learning about knowledge that contains education and political skills. Meanwhile, another definition states that a responsible citizen is the goal of Citizenship Education (28). Based on this opinion, Citizenship Education is an instrument in shaping the character of good citizens in the 
democratic process. Substantively, Civic Education is designed to produce 'good citizens' [29].

\subsection{The Digital Era}

Rapid flow of globalization cannot be dammed and avoided by everyone even a country,avoiding it is tantamount to closing themselves to the challenges of the times and causing lagging. The current of globalization caused many changes in various aspects of life.

Technological progress is very rapid in various fields, for example in the fields of transportation, communication, health, education, and other fields so as to make people increasingly need technology to facilitate all work in this life [30].

\section{METHOD}

This research aims to develop a product. The product in question is the Internalization Model of Political Education Values through Contextual Teaching And Learning (CTL) Approaches in Citizenship Education Subjects that can create political awareness of high school students. In order to make it easier for teachers to use this product, this product must be accompanied by procedures for how to pursue it, as well as the type of evaluation. The type of research that can be used to produce such a product is research and development (R\&D). According to Sugiyono (2008: 297) $R \& D$ is a research method used to produce certain products and tested their effectiveness. [31].

In order to be right on target in developing this model in high school, this research and development $(\mathrm{RnD})$ was carried out with the following steps:

1. Constructing a theoretical model; namely reviewing Political Education Policies in schools developed in Indonesia.

2. Describe the empirical model in SMA; namely reviewing related to the planting of political education carried out by SMAN 1 Garut which was then formulated in the form of a model.

3. Develop a hypothetical model to be tested, namely developing a new model for the benefit of senior high schools after analyzing and synthesizing from theoretical models and empirical models.

In developing Research and Development (R\&D) approach, there are ten steps of research, namely:

1. Determine the product design to be developed (hypothetical design):

2. Determine the research facilities and infrastructure needed during the research and development process.

3. Determine the stages of implementing the design test in the field.

4. Preliminary Field Test

5. Revision of Limited Field Test Results
6. Main Field Test

This step is a broader product test. This step includes:

a. Conduct product design effectiveness test;

b. The design effectiveness test, in general, uses the iterative model experiment technique;

c. The result of the field test is that an effective design is obtained, both in terms of substance and methodology. This book conducts a large class test, namely in a classroom learning situation on the subject of Citizenship Education (PKn). The researcher as an observer conducted a documentation study and interviewed school principals, teachers, students, parents and librarian.

7. Revision of Field Test Results is Wider

This step is the second improvement after conducting a wider field test than the first field test.

The improvement of the product from the results of this wider field test will further strengthen the product that we develop, because at the previous field trial stage it was carried out with a control group.

8. Feasibility Test

This step includes what should be done on a large scale:

a. Conducting product design effectiveness and adaptability tests;

b. Test the effectiveness and adaptability of the design involving potential users of the product;

c. The result of the field test is that a design model is ready to be applied, both in terms of substance and methodology.

9. Final Revision of Feasibility Test Results

This step will further refine the product being developed. Improvement of the final product is deemed necessary for more accurate products developed. At this stage, a product has been obtained whose effectiveness level can be accounted for. The final product refinement results have a reliable "generalization" value.

10. Dissemination and Implementation of Final Products

Reports on the results of $R \& D$ through scientific forums, or through the mass media. Product distribution must be done after going through quality control. The plan for the implementation of Dissemination at the West Java Provincial Education Office.

Prior to dissemination, the product is made in the form of an appropriate guide book for high school students with a predetermined color design and layout. Furthermore, dissemination can be carried out in the form of an appropriate final product and in accordance with the research results.

\section{RESULTS AND DISCUSSION}

Instilling political concepts at a young age, especially among high school students, is very 
important so that they do not get the wrong and wrong concept about politics. The importance of political education in adolescence will determine the high level of one's political awareness. The earlier an individual learns about politics, the higher his awareness of wanting to participate directly and being able to carry out responsibilities as a good citizen.

David Easton in Sirozi (2005, p. 49) says that 'one of the fundamental conditions for maintaining a political system is that when the younger generation in a society reaches adulthood, they must master the knowledge, values, and attitudes as expected. by members and existing systems. [32]. Based on David Easton's opinion, regardless of whether the country's political system is good or bad, if the system is to continue, then in a broad sense the system must be able to educate members of its society, especially the younger generation to play certain roles that are expected of them. .

Political education plays an important role in educating the younger generation to gain a clear understanding of various political concepts and symbols, especially in shaping their political awareness. Political education is a means for young people to mature their understanding of the fundamental political orientations that must be possessed in order to form high political awareness. A person's political awareness does not come by itself but through a long process. Although family, mass media, and political experience also determine the process of forming one's political consciousness, the role of educational institutions cannot be ruled out. This process can be obtained through various educational channels, both formal and informal. In the formal path, namely through the schooling path, an individual can more easily recognize and know the concepts of politics because it has been planned and has been prepared in detail through the existing curriculum.

The curriculum in schools as the most important component of education, can basically be used as a media for political education to instill and shape the growth of political awareness. This is based on the main source of curriculum making at the educational institution. Sudijono Sastroatmodjo (1995, p. 27) commented on the relationship between education and a person's level of political awareness as follows:

The level of education has an important role in increasing political awareness. The higher the level of public education, the higher the political awareness. Vice versa, the lower the level of public education, the lower the level of public political awareness. [33].

Students gain knowledge and understanding of politics at school through Citizenship Education lessons. It can be said that all subjects have a good goal, namely educating students so that they can become citizens according to expectations. But basically, subjects that specifically educate students to be good citizens (to be good citizenship) are charged to Citizenship Education because the material contained in it raises a lot about politics.

In the Civics curriculum there are several political materials which later with the delivery of political material are expected to provide students with an understanding of political information, which in turn can increase students' political awareness and further encourage students to participate in political activities in a small scope such as at school and in a wider scope, namely in the life of society, nation and state.

In schools, the implementation of political education is mainly carried out through Citizenship Education subjects and through other program activities. In Civics subjects there are materials that are a manifestation of the implementation of political education. At the high school level, especially in Class $\mathrm{X}$, there is material on the nature of the Nation and the Unitary State of the Republic of Indonesia (NKRI). There is also material on respecting the equality of citizens in various aspects of life and material on the political system in Indonesia. In Class XI there is material on political culture in Indonesia, and in Class XII there is material for various systems of government. The presence of political material in Civics subjects plays an important role in adding insight related to students' political knowledge. To get maximum results from Civics learning, the teacher in delivering political material is always guided by relevant learning sources and the information is always updated at any time based on the conditions and issues that occurred at that time. It is hoped that with these learning resources students will more easily understand and understand political material, especially once students get actual material based on the context that occurred at that time. Not only maximizing political learning by utilizing learning resources, teachers in teaching also use fun and participatory learning methods and models. The use of these learning methods and models is carried out with the consideration that students become interested in the lesson and ultimately can participate in learning. In the implementation of learning the teacher has designed a form of learning that is not only done in the classroom, but can also facilitate Civics learning outside the classroom. By learning outside the classroom, students learn to practice the theory they get when learning is done in the classroom. This practice can be done in the form of a simulation.

By doing simulations, students will understand better and understand more about the material given. On that basis, the Contextual Teaching And Learning learning approach is the choice, because this learning model aims to help students see meaning in academic material in the context of their daily lives, namely in the context of their personal, social, and cultural circumstances. This means that contextual learning allows students to relate the content of the material to the context of everyday life. So it is considered 
appropriate as a learning instrument to improve political literacy (political literacy) which is expected to have a positive and constructive impact on political knowledge as well as more substantive political awareness among high school students.

In addition, schools with various tools including curriculum, textbooks, teaching methods, existing organizations in schools, classroom environments, students, teachers, administrative structures and others, can be explicitly or implicitly related to transitions. fundamental political orientation. Fundamental political orientations are usually formed at an early age. The political orientation formed at that age will be deeply rooted and will continue throughout life, unless there is a very strong environment that influences the individual.

In internalizing the values of political education, especially in the learning process, teachers should design a form of learning that is not only carried out in the classroom, but can also facilitate learning outside the classroom with a CTL approach. and use digital instruments as tools. or effective learning media. So it is considered appropriate as a learning instrument in improving students' political literacy in the digital era.

\section{CONCLUSION}

Based on the results of the research and discussion above, the researcher formulates several conclusions as follows:

1. In realizing students' political awareness, it is necessary to strengthen political education and political literacy in a comprehensive and systematic manner according to the age of student development. So that in the future become a responsible national leader and bring Indonesia to be more advanced and civilized.

2. In implementing the internalization of the values of political education, especially in the learning process, teachers should design adaptive forms of learning with the needs of students. both in class and outside of class. By learning outside the classroom, students learn to practice the theory they get when learning is done in the classroom. This practice can be done in the form of a simulation. By doing simulations, students will better understand and understand more about the material given.

\section{REFERENCES}

[1] Chomsky, N.(2016). Who Rules the World ?. Yogyakarta: Bentang Pustaka

[2] Sirozi, M.(2005). Politik pendidikan: Dinamika hubungan antarakepentingan kekuasaan dan praktik penyelenggaraan pendidikan. RajaGrafindo Persada.

[3] Sastroatmodjo, S.(1995). Perilaku politik. Semarang: IKIP Press.
[4] Schwartz, S. H. (1994). Beyond individualism/collectivism: New cultural dimensions of values. In Kim, U., Triandis, H. C., Kagitcibasi, C., Choi, S.-C., \& Yoon, G. (Eds.), Individualism and collectivism: Theory, method, and applications.(pp. 85-119). Thousand Oaks, CA: Sage.

[5] Mulyasa, (2014). Manajemen Pendidikan Karakter. Jakarta : Bumi Aksara

[6] Hakam, K. A (2010). Model Pembelajaran Pendidikan Nilai.Bandung: CV Yasindo Multi Aspek

[7] Hakam, K. A. dan Nurdin, E.S. (2016). Metode Internalisasi Nilai- Nilai. Bandung: CV.Maulana Media Grafika.

[8] Kupchik, A dan Ellis, N. (2008). School Discipline and Security : Fair for All Students?. Journal: Youth and Society. Vol: 39 (4). 549-574. doi: 10.1177/0044118X07301956

[9] Maftuh, B. (2008). Internalisasi Nilai-Nilai Pancasila dan Nasionalisme Melalui Pendidikan Kewarganegaraan. Educationist. Vol. II No. 2, hlm. 134-144

[10] Pearson, Q.M \& Nicholson, J.I. (Juni 2000). Comprehensive character education in the elementary school. Journal of Humanistic Counseling, Education and Development; Jun 2000; 38, 4; ProQuest Education Journals pg. 243

[11] K. Affandi, Idrus \& Suryadi, "Teori dan Konsep dalam Konteks Pendidikan Politik," in PKNI4423/MODUL 1, Universitas Terbuka, 2016, pp. 1-19.

[12] C. Harber, "International Contexts for Political Education," Educational Review, vol. 43, no. January 2015, pp. 37-41, 2006.

[13] Halking, “Aspek-aspek Pendidikan Politik dalam Kehidupan Demokrasi untuk Mewujudkan Kecakapan Warga Negara yang Smart and Good Citizenship,"https://journal.unnes.ac.id/sju/index. php/snh http://fh.unnes.ac.id,vol. 4, no. 3, pp. 1205-1228, 2018.

[14] D. Sumantri Endang, Pendidikan Politik. Jakarta: Universitas Terbuka, 2003.

[15] K. Kartono, Pendidikan Politik sebagai Bagian dari Pendidikan Orang Dewasa. Bandung: Mandar Maju, 2009.

[16] E. O. S. Lyamu, "Citizenship education in Nigeria schools. Rationale and constraints.," Nigeria Journal of educators, vol. 2, no. 1, pp. 35-51, 1999. 
[17] Kantaprawira, R. (2004).Sistem Politik Indonesia, Suatu Model Pengantar, Edisi Revisi. Bandung : Sinar baru Algensindo.

[18] Surbakti, R. (1999).Memahami Ilmu Politik. Jakarta: Gramedia Widya Pustaka Utama.

[19] Komalasari, K.(2010). Pembelajaran Kontekstual, Konsep dan Aplikasi, Bandung: PT Refika Aditama.

[20] Suryanti. (2008). Model-model Pembelajaran Inovatif. Surabaya :UNESA University Press.

[21] Johnson, E.B. (2011). Contextual Teaching and Learning: Menjadikan Kegiatan Belajar-Mengajar Mengasyikkan dan Bermakna. Bandung: Kaifa.

[22] Suryanti. (2008). Model-model Pembelajaran Inovatif. Surabaya :UNESA University Press.

[23] Peraturan Menteri Pendidikan Nasional Nomor 22 Tahun 2006 tentang Standar Isi untuk Satuan Pendidikan Dasar dan Menengah.

[24] P. Crittenden, J., \& Levine, "Civic Education. In The Stanford encyclopedia of philosophy. Stanford, CA: Center for the Study of Language and Information, Stanford University," http://plato.stanford.edu/archives/sum2013/ entries/civiceducation, 2013.

[25] B. Ghebru and M. Lloyd, "From civic to citizenship education: Toward a stronger citizenship orientation in the Ethiopian CEE curriculum," International Journal of Educational Development, vol. 72, p. 102143, 2020.
[26] T. W. W. Yuen, "Civic Education stuck in a quagmire: A critical review of Civic Education in Hong Kong?," Citizenship, Social and Economics Education, vol. 15, no. 2, pp. 69-82, May 2016.

[27] Macmullen, “"Religious schools, Civic Education, and public policy: A framework for evaluation and ecision,"' Theory and Research in Education, no. X, pp. 1-21, 2018.

[28] J. Westheimer, J. and Kahne, "Educating the 'good' citizen: political choices and pedagogical goals," Political Science and Politics, vol. 37, no. 2, pp. 241-47, 2004.

[29] A. Mouritsen, Per \& Jaeger, Designing Civic Education for Diverse Societies: Models, Tradeoffs, and Outcomes. Berlin: Futures Working Group is a Migration Policy Institute Europe initiative,Robert Bosch Stiftung, 2018.

[30] Ikhwani, Yusril, “Analisis dan Rancangan Sistem E-Voting Pemilihan Ketua Osis," Technologia. vol. 9, pp. 138-143, September 2018

[31] Sugiono, (2016). Metode Penelitian dan Pengembangan. Bandung : Alfabeta.

[32] Sirozi, M.(2005). Politik pendidikan: Dinamika hubungan antarakepentingan kekuasaan dan praktik penyelenggaraan pendidikan. RajaGrafindo Persada.

[33] Sastroatmodjo, S.(1995). Perilaku politik. Semarang: IKIP Press. 